\title{
Analysis Unit Cost In Mild Head Injury Patient With Activity Based Costing Method At The Hospital In Yogyakarta
}

\author{
Sigit Kurniawan \\ Student of Hospital Management Program, Postgraduate Program, \\ University of Muhammadiyah Yogyakarta, \\ Lingkar Selatan Street, Kasihan Bantul, Yogyakarta, Indonesia \\ Firman Pribadi \\ Lecture of Hospital Management Program, PostGraduate Program. \\ University of Muhammadiyah Yogyakarta
}

\begin{abstract}
Background: The system used by the government to payment of tariff claim to hospital is by using INA-CBG's system (Indonesian Case Based Groups). The implementation of INA-CBG's system by the government make hospitals need to analyze expenditure cost in patient treatment, and take effort to effectively reduce cost expended, one of those is by using clinical pathway. Panembahan Senopati Bantul hospital has never conducted a cost evaluation based on clinical pathway for mild head injury, only in the case of appendicitis has been evaluated based on clinical pathway and compared with INA-CBG tariff obtained positive difference, the costs incurred by Hospitals are lower compared to INA-CBG "s tariff claims. One of the cost calculations in the hospital, by using analysis of unit cost. Research Objective: To analyzed the unit cost in mild head injury patient with Activity Based Costing method in Panembahan Senopati Bantul hospital. Method: This research did in Panembahan Senopati Bantul hospital. This research was kind of quantitative descriptive research. The subject of this research is chief financial officer, Surgical Specialist, Head of Ward Melati, pharmacy officer, medic record officer and mild head injury patient. Data analysis method used was Activity-Based Costing (ABC). Result: Unit cost calculation on inpatients with head injury diagnosis by Activity Based Costing method at Panembahan Senopati Bantul hospital obtained total cost as much Rp.2,301,989.30. Unit cost with $A B C$ method got difference between unit cost with real cost according to policy applied in RSUD Panembahan Senopati Bantul with difference of cost equal to Rp. 84.357,70. Unit cost with $A B C$ method got difference between unit cost with INA CBG's tariff which set by the government with difference of cost equal to Rp.146.810,70. Conclusion: Unit cost in mild head injury patients with ABC method in Panembahan Senopati Bantul hospital obtained lower cost than the real cost and INA CBG's tariff.
\end{abstract}

Keywords: Activity-Based Costing (ABC), Unit Cost, Mild head injury

\section{INTRODUCTION}

Increasing public demand for services in the health sector requires hospitals to always improve their human resource capacity so as to provide quality and professional services. These demands are both goals and motivations to provide health services in hospitals. On the other hand, the availability of government resources and subsidies aimed at financing public health services is increasingly limited. ${ }^{1}$

The Center for Financing and Health Insurance (2012) through its official website states that the increasing health costs make difficult for people to access the health services they need. This situation mainly occurs in circumstances where health financing should be borne (out of pocket) in the cash payment service system (fee for service). This increase in health costs is caused by the application of advanced technology, the character of "supply induced demand" in 
health services, and the pattern of direct cash payments to health providers, chronic and degenerative diseases, and inflation. ${ }^{2}$

On January 1, 2014 the government began implementing the National Health Insurance System (JKN) which began to change the health payment system initially fee for service into a prospective system known casemix (case based payment) Indonesia Case Based Group's (INACBG) system in under the Social Security Administering Body (BPJS). Case Base Groups (CBG's) are in principle the same as the Group's Diagnosis Related (DRG's) which is a system of rewarding health care services to health care providers defined by the classification of disease diagnoses as an effort to control costs without excluding quality health services, so that the health services provided are effective and efficient. ${ }^{3}$

The change in the prevailing system makes the hospital management department analyze the costs of the patient care, and makes efforts to effectively reduce costs effectively by using clinical phatway guidelines to treat patients.

Head injury is a mechanical trauma to the head either directly or indirectly causing impaired neurological functioning ie physical, cognitive, psychosocial, temporary or permanent psychotherapy. ${ }^{4}$ The incidence of head injuries in the United States (Advance Life Trauma Support (ATLS), 2004) annually reaches 500,000 cases where $10 \%$ die, $80 \%$ mild head injury (CKR), 10\% moderate head injury (CKS), and 10\% severe head injury (CKB). ${ }^{5}$ The Defense Centers of Exellence (2012) study showed more than 244,000 people experienced head trauma, $77 \%$ of whom had mild head trauma. ${ }^{6}$

One of the hospitals in Jakarta, Mangunkusumo Hospital has a CKR incidence rate of $60 \%-70 \%$ of patients, $15 \%-20 \%$ CKS and $10 \%$ CKB. The highest mortality rate of $35 \%-50 \%$ due to CKB and 5\% -10\% CKS. ${ }^{4}$ In addition Indonesia is also ranked first incident head injury caused by traffic accidents of 33.2\%. According to data from Basic Health Research (Riskesdas) 2007, $18.9 \%$ of traffic casualties suffered head injury. ${ }^{7}$ Polda DIY data shows that in 2012 there were 1,548 incidents in Sleman, 1,420 in Bantul, 678 in Yogyakarta, 453 in Gunung Kidul and 323 in Kulon Progo. ${ }^{8}$

One of the existing hospitals in Bantul Regency is Panembahan Senopati Bantul General Hospital. In accordance with Decree of Minister of Health No.142/Menkes/SK/I/2007 concerning the improvement of Class of Panembahan Senopati Bantul from type C to type B Education was inaugurated on 31 January 2007. Number of minor head injured patients who undergo inpatient at Panembahan Senopati Bantul Hospital 2016 were found 119 cases.

Based on the clinical pathway at Panembahan Senopati Bantul Hospital, this hospital has never been evaluated for cost calculation based on clinical pathway for mild head injury, only in case of appendicitis has been evaluated based on clinical pathway and compared with INA-CBG"s tariff got the positive difference, that is the cost incurred by the hospital is smaller compared with INA-CBG" s tariff claim. One of the cost calculations that exist in the hospital, namely by using unit cost analysis (unit cost).

The first activity based costing tally $(\mathrm{ABC})$ accounting system is, tracking the activity and then product costs. ABC (Activity Based Costing) is a financing based on production activity or service. ABC (Activity Based Costing) is an information system that identifies activities undertaken in the production process and tracks the costs of the activity. ${ }^{9}$ 
Many patients take advantage of BPJS health insurance to get inpatient treatment for mild cases of head injury. With the tariff set by the government, the hospital needs to make adjustments with the tariff. Therefore, we need to do cost analysis of mild head injury patient service in order to minimize the hospital's loss. Based on this background, the researcher was interested to conduct research entitled "Analysis of Unit Cost in Mild Head Injury Patient with Activity Based Costing Method in Panembahan Senopati Bantul Hospital”.

On the basis of the background that has been described previously, then the formulation of the problems raised in this study are:

1. What is the unit cost of CKR patients calculated using Activity Based Costing (ABC) method at Panembahan Senopati Bantul Hospital?

2. Is there any difference between unit cost of CKR patient using Activity Based Costing (ABC) method with real cost in CKR patient at Panembahan Senopati Bantul Hospital?

3. Is there any gap/differencebetween unit cost of CKR patient by using Activity Based Costing method with INA CBG'S tariff in CKR patient at Panembahan Senopati Bantul Hospital?

\section{RESEARCH METHOD}

The type of this research was descriptive by using quantitative approach. Cost data in this research was cost data in 2016 which was processed in accordance with unit cost calculation step by using Activity Based Costing (ABC) method. ${ }^{10}$

Subjects in this study were the chief financial officer, Surgical Doctor, Head of Melati Ward, pharmacy officer, medical record officer and Patient mild head injury. The object of this study were all activities that occurred in the care of inpatient class III with the diagnosis of mild head injury until the patient came home from the hospital.

The data analysis technique was done by taking primary data conducted by interview and observation, and secondary data obtained from clinical pathway of mild head injury patient and RSUD Panembahan Senopati Bantul Hospital record. While secondary data retrieval in this research was clinical pathway of mild head injury patient and also medical records of RSUD Panembahan Senopati Bantul.

\section{RESULTS AND DISCUSSION}

According to Baker (1998) Unit cost calculation by Activity Based Costing method on Inpatient of Mild Head Injury in Panembahan Senopati Bantul Hospital used the following stages: ${ }^{11}$

\section{Determining actvity centers related, cost and cost driver of each cost category.}


Table 1. Center Activities in the Emergency Instalation Unit

\begin{tabular}{|l|c|l|}
\hline Activity Center & $\begin{array}{l}\text { First Stage } \\
\text { Cost Drivers }\end{array}$ & Second Stage Cost Drivers \\
\hline Patients Administration & Time & Number of Patients come \\
\hline Patients reception & Time & Number of Patients come \\
\hline Early checkup of patients & Time & Number of Patients come \\
\hline Checkup of patients by doctor & Time & Number of patients \\
\hline Vital sign checkup & Time & $\begin{array}{l}\text { Number of medical record } \\
\text { submission }\end{array}$ \\
\hline Writing patient's medical records & Time & Number of prescription \\
\hline Prescription writing & Time & Number of activity \\
\hline $\begin{array}{l}\text { Preparing and administering } \\
\text { medications }\end{array}$ & Time & Number of actions \\
\hline Installation of intra vein line & Time & Number of checkup \\
\hline ECG Check & Time & Number of activity \\
\hline Blood sampling & Time & Number of new patients \\
\hline $\begin{array}{l}\text { Patient delivery to radiology for } \\
\text { CT-Scan, and cranium R0 }\end{array}$ & Time & Number of activity \\
\hline Installation of identity bracelet & Time & Number of activity \\
\hline Patient delivery to the ward & Time & Jumlah aktivitas \\
\hline $\begin{array}{l}\text { Provision of cover letter } \\
\text { administration completion }\end{array}$ & Time & Jumlah aktivitas \\
\hline $\begin{array}{l}\text { Completion of the Surgical } \\
\text { Polyclinic control letter }\end{array}$ & Time & Jumlah aktivitas \\
\hline Take the patient home & & \\
\hline
\end{tabular}

Tabel 2. Center Activity in Melati Ward Unit

\begin{tabular}{|l|c|l|}
\hline Activity Center & $\begin{array}{l}\text { First Stage } \\
\text { Cost Drivers }\end{array}$ & Second Stage Cost Drivers \\
\hline Preparation of the room & Time & Number of preparation \\
\hline Receive new patients & Time & Number of patients \\
\hline The file handover & Time & Number of new patient \\
\hline Orientation of the room & Time & Number of new patient \\
\hline $\begin{array}{l}\text { Assessment and risk interventions } \\
\text { fall patients }\end{array}$ & Time & $\begin{array}{l}\text { Number of medical record } \\
\text { submission }\end{array}$ \\
\hline $\begin{array}{l}\text { Charging medical record (nursing } \\
\text { care) }\end{array}$ & Time & $\begin{array}{l}\text { Number of preparation and } \\
\text { prescription }\end{array}$ \\
\hline $\begin{array}{l}\text { Preparing and administering } \\
\text { medications }\end{array}$ & Time & Number of actions \\
\hline Drug injection & Time & Number of activity \\
\hline $\begin{array}{l}\text { Monitoring the general state and } \\
\text { vital sign of the patient }\end{array}$ & Time & Number of activity \\
\hline Explanation of the disease & Time & Number of activity \\
\hline Release of infusion & Time & Number of activity \\
\hline Completeness of patient home & Time & Number of activity \\
\hline $\begin{array}{l}\text { Provision of cover letter } \\
\text { administration completion }\end{array}$ & $\begin{array}{l}\text { Nompletion of the Surgical } \\
\text { Polyclinic control letter }\end{array}$ &
\end{tabular}




\section{Charging the direct costs expended on the Impatient Light Head Injury}

Table 3. Direct cost of IGD Unit

\begin{tabular}{|l|c|c|r|}
\hline \multicolumn{1}{|c|}{ Cost Category } & Unit & Total Unit & \multicolumn{1}{c|}{ Total } \\
\hline Registration of IGD & Activity & 1 & 5.000 \\
\hline Examination of IGD doctor & Action & 1 & 32.500 \\
\hline Cranium Rontgen & Action & 1 & 90.000 \\
\hline Blood Complete & Action & 1 & 44.000 \\
\hline EKG & Action & 1 & 58.000 \\
\hline Head CT scan & Action & 1 & 400.000 \\
\hline Medication of minor injuries & Action & 1 & 26.500 \\
\hline 02 & liter & 3 & 33.000 \\
\hline Nasal 02 Adult & Biji & 1 & 13.800 \\
\hline Ringer Lactate Infusion & Flb & 1 & 8.223 \\
\hline Macro infusion set (01-64) & Pcs & 1 & 11.966 \\
\hline Abocath no 16 & Pcs & 1 & 9.540 \\
\hline Hipafix 10 x 500 & Pcs & 2 & 448 \\
\hline Identity Bracelet & Pcs & 1 & 2.090 \\
\hline Spuit 5 cc & Pcs & 4 & 4.500 \\
\hline Citicolin Injection 250 mg & ampoule & 1 & 16.040 \\
\hline Injection of Ranitidine 50 mg & ampoule & 1 & 3.795 \\
\hline Injection Ketorolak 30 mg & ampoule & 1 & 14.830 \\
\hline sterile handscoon no 7 & Pcs & 1 & 7.590 \\
\hline 6x9 folding gauze & Sheet & 2 & 1.100 \\
\hline Alcohol swab & Pcs & 2 & $\mathbf{7 8 3 . 1 7 6}$ \\
\hline
\end{tabular}

Tabel 4. Direct Cost of Melati Ward

\begin{tabular}{|l|c|c|r|}
\hline \multicolumn{1}{|c|}{ Cost Category } & Unit & Total Unit & \multicolumn{1}{c|}{ Total } \\
\hline Class III / day room rental fee & Activity & 2 & 50.000 \\
\hline Visite Specialist Surgeon & Activity & 2 & 70.000 \\
\hline Nutrition Accommodation & Feed & 2 & 30.000 \\
\hline Nasal canul Adult & Pcs & 1 & 12.000 \\
\hline Ringer Lactate Infusion & Flb & 2 & 16.446 \\
\hline cefotaxim injection & ampoule & 2 & 17.076 \\
\hline Injection of Ranitidine 50 mg & ampoule & 2 & 37.950 \\
\hline sterile handscoon no 7 & Pcs & 1 & 7.590 \\
\hline 6x9 folding gauze & sheet & 2 & 1.100 \\
\hline Alcohol swab & Pcs & 2 & 254 \\
\hline Spuit 5 cc Tcs & 1 & 1.125 \\
\hline Amoxicillin & Tab & 15 & 3.480 \\
\hline Mefenamic acid 500 mg & Tab & 10 & 1.730 \\
\hline \multicolumn{2}{|c|}{ Total Direct Cost } & & $\mathbf{2 4 8 . 7 5 1}$ \\
\hline
\end{tabular}




\section{Determine the indirect resource overhead cost}

\begin{tabular}{|l|r|}
\hline \multicolumn{1}{|c|}{ Jenis Biaya } & \multicolumn{1}{c|}{ Cost (Rp) } \\
\hline Labour Related & \\
\hline Staff & 25.709 .053 .905 \\
\hline Equipment Related & \\
\hline Reduction cost of medical and non-medical equipment & 8.396 .763 .583 \\
\hline Space Related & 1.715 .213 .104 \\
\hline Maintenance cost of equipment and building & 1.209 .314 .042 \\
\hline Reduction cost of building & \\
\hline Service Related & 1.682 .866 .460 \\
\hline Cost of Electric, Water, and Telephone & 2.538 .158 .929 \\
\hline Cost of Cleanliness & 1.976 .282 .325 \\
\hline Cost of Office Stationery and Houseware & $\mathbf{4 3 . 2 2 7 . 6 5 2 . 3 4 8}$ \\
\hline \multicolumn{2}{c}{ Total } \\
\hline
\end{tabular}

Tabel 5. The proportion of revenues of each unit

\begin{tabular}{|l|r|r|r|}
\hline \multicolumn{1}{|c|}{ Unit } & $\begin{array}{r}\text { Total of Earning } \\
\text { year of 2016 (a) }\end{array}$ & \multicolumn{1}{c|}{ (\%) (c) } & \multicolumn{1}{c|}{ Cost (Rp) (d) } \\
\hline Emergency departments & 2.685 .161 .652 & $3.61 \%$ & $1.559 .862 .006,87$ \\
\hline Outpatient & 9.705 .399 .708 & $13.04 \%$ & $5.638 .053 .208,18$ \\
\hline Inpatient & 22.176 .373 .342 & $29.80 \%$ & $12.882 .681 .458,36$ \\
\hline Central Surgical Installation & 12.084 .071 .374 & $16.24 \%$ & $7.019 .869 .291,89$ \\
\hline Hemodialysis & 8.946 .097 .333 & $12.02 \%$ & $5.196 .959 .866,33$ \\
\hline Electromedics & 642.512 .333 & $0.86 \%$ & $373.247 .762,18$ \\
\hline Pharmacy & 1.602 .333 .333 & $2.15 \%$ & $930.826 .226,85$ \\
\hline Laboratory & 11.769 .413 .703 & $15.82 \%$ & $6.837 .078 .603,74$ \\
\hline Radiology & 2.811 .378 .352 & $3.78 \%$ & $1.633 .183 .713,33$ \\
\hline Nutrition & 1.567 .103 .667 & $2.11 \%$ & $910.360 .636,44$ \\
\hline Medical records & 422.657 .000 & $0.57 \%$ & $245.529 .573,89$ \\
\hline Total & $\mathbf{7 4 . 4 1 2 . 5 0 1 . 7 9 8}$ (b) & $\mathbf{1 0 0 . 0 0 \%}$ & $\mathbf{4 3 . 2 2 7 . 6 5 2 . 3 4 8 , 0 5}$ \\
\hline $\begin{array}{l}\text { Info : (c=a:b*100\%), (d=c*e), a=Number of Earning, b= Number of } \\
\text { (percent), d= each installation cost, e=total cost }\end{array}$ & Earning, c=proportion \\
\hline
\end{tabular}

1) IGD

Unit IGD get a charge of Rp.1.559.862.006,87. The total cost is then charged to all IGD patients. The total number of patients with IGD in 2016 is 23,711 patients, so for one patient will get the cost of indirect resource overhead cost of Rp. 65786,43. The division is done based on one-off activities conducted in the Emergency Installation Unit (IGD).

2) Melati Ward

Inpatient of Panembahan Senopati Bantul General Hospital received indirect resource overhead fee of Rp.12.882.681.458,36. One of the inpatient units in Panembahan Senopati Bantul Hospital is Mealti Ward. Melati ward is a class III ward and has a 
number of beds as many as 27 of the total 297 beds contained in Panembahan Senopati Bantul Hospital. For indirect resource overhead calculation, Melati Ward get charge of Rp.1.171.152.859,85.

The cost of the overhead indirectly charged by the patient will be proportioned to impose the cost of indirect resource overhead per each day of care (LOS). Ward of Jasmine in 2016 has the number of day care for 5,642 hospital day, so for every day of care, then one patient gets the cost of indirect resource overhead cost equal to Rp.207.577,61.

\section{Determine Direct Resource Overhead}

1) IGD

The cost of direct resource overhead unit cost The emergency department obtained a fee of RP.1.943.144.041,74. The total cost will then be charged to all IGD patients Panembahan Senopati Bantul Hospital in 2016 many as 23,711 patients, then for one patient will get the cost of direct resource overhead of RP. 81.951,16.

2) Melati Ward

The cost calculation of Direct Resource overhead of Melati ward unit in 2016 is Rp.1,174,933,723,71, which is then charged to all patients on the basis of loading the number of day care of Melati Ward unit during 2016 is 5,624 days. So one patient in the Melati ward unit gets a direct resource overhead cost of Rp. 208.247,74.

\section{Determine overhead cost per activity}

1) IGD

The cost of overhead per activity on the IGD unit is obtained indirect resoutce overhead cost of Rp. 65,786,43, and direct resource overhead costs amounting to Rp.81.951,16

2) Melati Ward

The cost of overhead per activity on Melati ward unit was obtained indirect resource overhead cost of Rp. 207,577.61, and direct resource overhead costs of Rp.208.247,74.

\section{Determine Activity Centers related to Patients Care for Mild Head Injuries contained in clinical pathways and charge overhead into each activity centers in the clinical pathway.}

1) IGD

The cost of Indirect resource overhead in IGD unit which has been calculated based on activity in clinical pathway for diagnosis of CKR, the total cost obtained is Rp.65.786,43, while the cost of direct resource overhead on the IGD unit in total based on clinical pathway obtained cost calculation that is amounting to Rp.81.951,16

2) Melati Ward

The indirect Resource Overhead cost calculation on Melati Ward as calculated based on activity in clinical pathway was obtained total cost Rp.560.258,01, while the cost of direct resource overhead based on activity in clinical pathway at Melati wards unit, obtained total cost of Rp.562.066,70 


\begin{tabular}{|c|c|c|c|}
\hline \multicolumn{4}{|c|}{$\begin{array}{l}\text { Summing up the direct costs and overheads in the Light Head Injury Patient care in } \\
\text { RSUD Panembahan Senopati Bantul. }\end{array}$} \\
\hline \multicolumn{3}{|c|}{ Structure of Cost } & Cost \\
\hline \multicolumn{3}{|c|}{ Direct Cost Diagnosis Light head injury } & \\
\hline \multicolumn{2}{|l|}{ IGD } & 783.176 & $1.031 .927,00$ \\
\hline \multicolumn{2}{|l|}{ Bangsal Melati } & 248.751 & \\
\hline Overhead Cost & $\begin{array}{l}\text { Indirect Resource } \\
\text { Overhead }\end{array}$ & $\begin{array}{l}\text { Direct Resource } \\
\quad \text { Overhead }\end{array}$ & Total Overhead \\
\hline $\begin{array}{l}\text { Overhead Cost of } \\
\text { IGD }\end{array}$ & $65,786.43$ & $81,951.16$ & $147,737.59$ \\
\hline $\begin{array}{l}\text { Overhead Cost of } \\
\text { Melati Ward }\end{array}$ & $560,258.01$ & $562,066.70$ & $1,122,324.71$ \\
\hline \multicolumn{3}{|c|}{ Total Cost } & $2.301 .989,30$ \\
\hline
\end{tabular}

The calculation of unit cost of inpatients with mild head injury at Panembahan Senopati Bantul Hospital with Activity Based Costing method was obtained total cost of Rp.2.301.989,30 with total direct cost of Rp. 1,031,927, and the total overhead cost is Rp.1.270.062,30.

\section{DISCUSSION}

\section{Direct Cost Charges in Unit Cost Calculation Diagnosis of Mild Head Injury}

Direct costs are fees that can be charged directly to cost or product objects such as consumable costs, specialist medical services and laundry linens. Direct costing is not a generally accepted accounting procedure for external reporting purposes, as the exclusion of all overheads from inventory is not compliant with the definition of production cost. ${ }^{12}$

Based on the result of research, known that direct cost in calculation of unit cost of patient care with diagnosis of mild head injury at RSUD Panembahan Senopati Bantul is Rp. 1,031,927. The calculation of the direct costs consists of the cost of the IGD unit and the Melati Ward unit. In

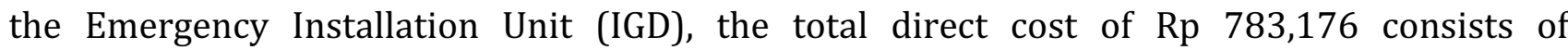
supporting costs of Rp 618,500 and the cost of medicines, consumables of Rp 127,176, while the direct cost of Melati ward unit is Rp248.751. Direct cost calculations for patients with head injury are obtained based on the cost of consumables adapted to the Clinical Pathway for the diagnosis of mild head injuries during patient care at Panembahan Senopati Bantul Hospital.

The examination of CKR patients starts at the IGD unit, the patient was examined by the Emergency Installation Unit duty physician and then examined in the form of Blood Complete, EKG, Rontgent Cranium and Head CT Scan. One of the investigations on Headache Injuries is Head CT Scan. Head CT Scan is one of the procedures contained in clinical pathway to establish diagnosis of mild head injury.

In this research, direct cost calculation on Melati ward unit is Rp. 248.751 with details of drug costs, consumables found in Melati Ward is Rp. 98751. The cost of the room, visite doctor surgeon and nutrition accommodation is Rp. 150,000. Length of stay (LOS) of patients with mild head injury on average treatment is 2-3 days depending on the clinical condition or the patient's condition. In this study the length of the patient's hospitalization of Mild Head Injury is for 2 days according to the clinical pathway. Treatment of CKR patients who have shorter hospitalization time can reduce the cost because of longer maintenance time or higher Length of stay (LOS) can cause more and more expense. 
The results of a study conducted by Chatterjee, Levin and Laxminarayan (2013) show "One reason for the overhead high cost at the outpatient and inpatient departments of the privilege can be focused on cases, which ones may be few." 13 Reason for the high the overall costs of outpatient and hospitalization can be due to some special cases that should get the focus of the hospital, but the cases are likely to be few. The hospital needs to determine the foster road load or revenue can be increased to improve unit cost.

Based on interviews with IGD doctors at Panembahan Senopati Bantul Hospital that for investigations such as GDS and EKG are not all done on the care of patients Mild Head Injury. Examination of GDS and EKG is only done under certain conditions depending on the patient's clinical condition such as the history of Diabetes mellitus disease, the patient has shortness of breath, chest pain, or the patient has previous history of heart disease. This is what causes the difference in the cost calculation in each patient.

\section{Overhead costs in the calculation of unit cost of patient care with diagnosis of Mild Head Injury (CKR)}

Based on the research results obtained total overhead in accordance with clinical pathway for the diagnosis of head injury in RSUD Panembahan Senopati Bantul Rp.1.270.062,30. Overhead or indirect expenses are outlays that are incurred in achieving project completion but that do not apply directly to any specific work item. ${ }^{14}$

Calculation of Overhead cost consists of two units, namely overhead cost of Emergency Installation Unit (IGD) and overhead cost of Melati Ward unit. The total overhead cost of the Emergency Installation Unit (IGD) was Rp.147.737,59, which consisted of indirect resource overhead cost of Rp.65.786,43 and direct resource overhead cost of Rp.81.951,16. The calculation of unit cost of patient care with diagnosis of head injury according to clinical pathway on Melati Ward unit got total cost of overhead equal to Rp. 1.122.324,71, which consists of indirect resource overhead cost of Rp. 560.258.01 and direct resource overhead cost of Rp. 562.066,70.

In this study the calculation of direct resource overhead cost is greater than the cost of indirect resource overhead, both in Emergency Installation Unit (IGD) and Melati Ward unit. According to the researchers the high cost of direct resource overhead is due to the cost of charging only charged to one functional unit that is the unit itself, while the calculation of indirect resource overhead cost is lower because the total cost is charged to all functional units in hospital such as Emergency Installation Unit IGD) get the cost of 3.61\%, the outpatient unit is 13.04\%, the hospitalization unit is $29.80 \%$, the central surgery installation unit is $16.24 \%$, the hemodialysis unit is $12.02 \%$, the electromedical unit is $0.86 \%$, Pharmacy unit $2.15 \%$, Laboratory unit $15.82 \%$, Radiology unit $3.78 \%$, Nutrition unit $2.11 \%$, and medical record unit $0.57 \%$. The nearly of overhead costs and total costs in the setting of increased inpatient days and decreased inpatient bed capacity suggests that hospitals have failed to control overhead costs. 15

The calculation of overhead cost both on indirect resource overhead and direct resource overhead in the calculation has four categories: labor related, equipment related, space related, and service related. Labor related consists of the cost of salary. The hospital unit cost studies from developing countries reported that human resource was the largest component of the total cost of a hospital. ${ }^{16}$ The total cost of Panembahan Senopati Bantul hospital employee in 2016 was Rp.25.709.053.905. RSUD Panembahan Senopati Bantul itself has an employee number of 819 people, consisting of 450 civil servants (civil servants) and non-civil servants as 
many as 369 people. In the IGD unit the amount of salary costs of employees to be issued by the hospital amounted to Rp.1.026.000.000, with a total number of IGD employees of 43 people consisting of 15 general practitioners, 24 nurses, and administrative officers of 4 people. Total cost of employees who must be issued hospital on Melati unit manny as Rp. 486,337,000 with total number of employees as many as 20 employees consisting of the number of nurses as many as 18 people, and administrative officers as much as 2 people. Equipment related consists of the cost of depreciation of medical and non medical equipment with total hospital cost of Rp.8,396,763,583, Space related consists of the cost of building depreciation and maintenance cost of equipment and buildings with total hospital costs of Rp.2,924,527,146, and Service related consisting of electricity, water, telephone, hygiene cost, ATK cost and household appliances, got total hospital cost Rp. 6.197.307.714.

The study by Kalman et al (2015) states that "this study's inclusion of staff salaries in the calculation of overhead costs is likely led to the higher percentage. The calculation of costs with the addition of salary to the staff can cause the percentage of overhead costs to be higher. To overcome the cost of care adequately, the hospital needs to overcome the overhead as well as direct patient costs. ${ }^{17}$

\section{Unit cost of Patient Head Injury to Melati Ward (class III) through Activity Based Costing (ABC) calculation as well as difference with mild head injury treatment tariff and INA CBGs tariff in RSUD Panembahan Senopati}

Based on the calculation of unit cost in inpatients with diagnosis of head injury with Activity Based Costing method in RSUD Panembahan Senopati Bantul obtained unit cost of Rp.2.301.989,30 with direct cost of Rp. 1,031,927, and overhead cost of Rp.1.270.062,30. Calculation of Real Cost in accordance with the management policy applied hospital is Rp. 2.386.357,00, while INA CBG's tariff for diagnosis of Mild Head Injury set by the government with ICD BPJS SO6.0 coding is Rp. 2.448.800,00.

Table 6 Unit cost method of Activity Based Costing (ABC), Real Cost, and Rates of INA CBGs Mild Headache Injury treatment in inpatient class III patients in 2016

\begin{tabular}{|c|c|c|}
\hline Unit Cost & Real Cost & Tarif INA CBGs (Rp) \\
\hline $2.301 .989,30$ & $2.386 .357,00$ & $2.448 .800,00$ \\
\hline
\end{tabular}

In table 6 found that the calculation of unit cost with ABC method obtained cost of Rp. $2,301,989.30$. Total cost is lower than the cost of hospital's real cost with the difference in cost of Rp. 84,367.70, which means that the real cost tarrif is able to cover both direct and overhead costs at the hospital. In this study it was found that unit cost calculation was lower compared to INA CBG's tariff set by the government with cost difference of Rp.146,810.70, while the real cost tariff applied by the hospital is found to be lower cost with INA CBG's tariff with a cost difference of Rp. 62.443.00. In the calculation of unit cost is obtained the total cost is lower than the real cost and INA CBG's tariff set by the government. Therefore, according to researcher, the hospital might need to evaluate the existing tariff so that the difference or cost difference between unit cost, real cos, and INA CBG's tariff is not too big so it can reduce the loss rate of the hospital.

The difference between unit cost calculated by Activity Based Costing method because the calculation method used is different. Unit cost calculated in this study was calculated based on Clinical Pathway CKR diagnosis that was applied in RSUD Panembahan Senopati Bantul. 
According to Rahmanto (2009) Clinical Pathway (a medic service flow) is an integrated service concept that summarizes every step given to patients based on medical service standards, nursing care standards, and other standards of health-based, evidence-based service with measurable results and within a certain time during the hospital. The advantages and benefits of Clinical Pathway can support the introduction of Evidence Based Medicine, improve communication among teamwork disciplines, provide clear and good standards for service activities, help reduce variation in patient care (through standards), improve resource management processes. The theory is in accordance with the results of research conducted by Huang et al (2015) shows that the benefits of clinical pathway implementation that can reduce the average length of hospitalization, reduce inpatient expenses, improve patient satisfaction, and improve the quality of hospital management resources. ${ }^{18}$

In this study the results of unit cost calculation by $A B C$ method is expected to provide information about the calculation of more accurate cost, so it can be used by the hospital management in determining the tariff. ABC system constitutes the cause-and-effect relationship between activities and cost objects and provides information on the actual unit cost of providing clinical services in hospital. ${ }^{19}$ Based on observations from researcher on the use of Clinical pathway for mild Head Injury in Panembahan Senopati Bantul Hospital, the use of clinical pathway can not be used in CKR patients with other comparisons such as fracture because it will affect the total cost and the determination of the CKR diagnosis tariff if accompanied by compilation or not.

The medic services in Panembahan Senopati Bantul Hospital are Deep Disease, Child Health, Surgery, Obstetrics and Gynecology, Anesthesiology, Radiology, Rehabilitation Medic, Pathology Clinic, Eyes, skin, THT, Nerve, Heart, Lung, psikiatri and Orthopedic Medicine. This is in accordance with Minister of Health Decree No. 340 / Menkes / PER / III / 2010 on classification of Hospital Article 10 stating that Class B Hospital must have facilities and medic service capability of at least 4 basic medical services (Internal Medicine, Obstetrics and Gynecology), 4 Specialist Support Services (Anesthesiology, Radiology, Rehabilitation Medic and Pathology Klnik), and other specialist medical services at least 8 of 13 services (Eyes, THT, Nerve, Heart, Skin, Lung, Orthopedics, Urology, Neurosurgery, Plastic Surgery and Forensic Medicine). For specialist Surgery at RSUD Panembahan Senopati Bantul only have a specialist General Surgery as much as 3 people. Based on an interview with one of the surgeons that for one of the CKR's diagnosis is to use GCS (Glasgow Coma Scale). For care CKR actually must be handled by a neurosurgeon, therefore CKR patient care should always be observation. If the patient is experiencing a deterioration or leads to moderate head injury (CKS) or severe head injury (CKB) then the patient should be immediately referred to a hospital that has adequate facilities, one of which is a hospital that has a specialist neurosurgeon. The absence of a neurosurgeon in the hospital will have an impact on the quality of care provided to the patient. In the future the hospital might need to provide a neurosurgeon doctor from the high incidence of CKR in Panembahan Senopati Bantul Hospital in 2016 which was 119 patients, so that the future of patient care can be more comprehensive.

\section{CONCLUSION}

Unit cost calculation on inpatients with diagnosis of Mild head injury with Activity Based Costing (ABC) method at Panembahan Senopati Bantul Hospital obtained total cost of Rp.2,301,989.30. Unit cost calculation by Activity Based Costing method got difference between unit cost with real cost according to policy applied in Panembahan Senopati Bantul Hospital with cost difference equal to Rp. 84.357,70.

Calculation of unit cost with Activity Based Costing method got difference between unit cost 
with INA CBG's tariff which determined by government with cost difference equal to Rp.146.810,70. Based on these calculations, it can be concluded that unit cost in patients with Mild Head Injury (CKR) with Activity Based Costing method found lower cost results compared to real cost and INA-CBG's tariff.

\section{Reference}

Sugiyarti, 2013, Analisis Biaya Satuan Unit Cost Dengan Metode Activity Based Costing ABC Studi Kasus di Poli Mata RSD Balung Kabupaten Jember. Jurnal Pustaka Kesehatan, vol 1, no. 1, September 2013.

Pusat Pembiayaan dan Jaminan Kesehatan, 2012, Pembiayaan dan Jaminan Kesehatan, tersedia online, http://www.ppjk.depkes.go.id/index.php?option=com_content\&view=article\&id=1:selamat-datangdi pembiayaan-a-jaminan-kesehatan- online\&catid=56\&Itemid=28 diakses pada 15 Maret 2017.

Sari RP, 2014, Perbandingan Biaya Riil Dengan Traif Paket INA-CBG"s Dan Analisis Faktor Yang Mempengaruhi Biaya Riil Pada Pasien Diabetes Mellitus Rawat Inap Jamkesmas di RSUP Dr. Sardjito Yogyakarta, Jurnal Spread, vol.4, no. 1, hh. 61-70.

PERDOSSI, 2003, Simposium trauma kranio-serebral tanggal 3 November 2007. Pekanbaru Hickey JV. Craniocerebral Trauma. Dalam: The Clinical Practice of Neurological and Neurosurgical Nursing $5^{\text {th }}$ edition. Philadelphia : lippincot William \& Wilkins, 2003

Defense Centers of Exellence, 2010, Assessment and Management of Dizziness Associated with Mild TBI. http://www.dcoe.mil/Content/Navigation/Documents/Dizziness_Associated_with_Mild_TBI_Clinical_Recommen dation.pdf

American College of Surgeon Committee on Trauma, 2004, Cedera Kepala dalam Advanced Trauma Life Support for Doctors. Ikatan Ahli Bedah Indonesia. Komisi trauma IKABI.

Riyadina, W, dkk, 2009, Pola Determinan Sosiodemografi Cedera Akibat Kecelakaan Lalu Lintas di Indonesia. Majalah Kedokteran Indonesia Vol 59 No 10, Jakarta.

Dinkes DI, 2013, Profil Kesehatan Daerah Istimewa Yogyakarta Tahun 2013, Dinas Kesehatan D.I. Yogyakarta, Yogyakarta.

Sugiyono, 2014, Metode Penelitian Manajemen, Alvabeta, Bandung.

Mowen dan Hansen, 2009, Akuntansi Menejerial, Edisi 8, Salemba Empat, Jakarta

Baker, J., J. 1998. Activity based costing and activity based management foe healthcare, aspen publisher, inc.

Nunea Bontas Christina. 2013. The Cost Of Production Under Direct Costing And Absorption Costing - A Comparative Approach. ACADEMICA BRÂNCUȘI" PUBLISHER, ISSN 1844 - 7007

Chatterjee, Susmita Carol, Levin and Ramanan Laxminarayan. 2013. Unit Cost of Medical Services at Different Hospitals in India. Journal PLos ONE 8(7)

Budapest University of Technology and Economics, Department of Construction Technology \& Management, Hungary. 2011. Cost calculation methods

Spring. 2015. Hospital Overhead Costs: The Neglected Driver of Health Care Spending?. Journal of Health Care Financ

Than, Saw, Khaing, Win, Cho, Kariya, Yamamoto and Hamajima. 2017. Unit cost of healthcare services at 200-bed public hospitals in Myanmar: what plays animportant role of hospital budgeting?. BMC Health Services Research (2017) 17:669 DOI 10.1186/s12913-017-2619-Z

Kalman, Noah S., MD; Bradley G. Hammill, MS; Kevin A. Schulman, MD; Bimal R. Shah, MD, MBA. 2015. Hospitals Overhead Costs: The Neglected Driver of Health Care Spending. Journal of Health Care Finance

Huang D, Song S, Tian J, Cui Q, Yang K. 2015. Effects of clinical pathways in stroke management: a meta-analysis. Neurol Asia.; 20(4):335-42

Haidan and Salehi. 2016. Application of the Activity-Based Costing Method for Unit-Cost Calculation in a Hospital. Global journal of health science · January 2016 